\title{
Prevalence of nonmotor symptoms in patients with Parkinson's disease in Split-Dalmatia County
}

\author{
Slaven Lasić ${ }^{1}$, Silvio Bašicíc ${ }^{1,2}$, Davor Sporiš̌l, ${ }^{1,2}$ Gordan Džamonja ${ }^{3,4}$ \\ Department of Neurology, University Hospital Dubrava, Zagreb, Croatia; \\ 2 School of Medicine, Josip Juraj Strossmayer University, Osijek, Croatia; \\ ${ }^{3}$ University Department of Neurology, Split University Hospital Center, Split, Croatia; \\ ${ }^{4}$ School of medicine, University of Split, Split, Croatia
}

OPEN ACCESS

Correspondence:

Slaven Lasić

lasicslaven1993@gmail.com orcid.org/0000-0002-3341-7625

This article was submitted to RAD CASA - Medical Sciences as the original article

Conflict of Interest Statement: The authors declare that the research was conducted in the absence of any commercial or financial relationships that could be construed as a potential conflict of interest.

Received: 10 May 2021 Accepted: 24 May 2021 Published: 15 June 2021

Citation: Lasić S, Bašić S, Sporiš D, Džamonja G. Prevalence of nonmotor symptoms in patients with Parkinson's disease in Split-Dalmatia County RAD CASA - Medical Sciences. 547=54-55 (2021): 38-48 DOI: https://dx.doi.

org/10.21857/90836c760y

Copyright (C) 2021 Lasić S, Bašić $\mathrm{S}$, Sporiš D, Džamonja G. This is an open-access article distributed under open-access article distributed under
the terms of the Creative Commons Attribution License (CC BY). The use, distribution or reproduction in other forums is permitted, provided the original author(s) and the copyright owners(s) are credited and that the original publication in this journal is cited, in accordance whit accepted adacemic practice. No use, distribution or reproduction is permitted which or reproduction is permitted which
does not comply with these terms.

\section{ABSTRACT:}

Introduction: This study aimed to review the prevalence of NMS in patients with Parkinson's disease in Split-Dalmatia County and to investigate the effects of other variables on the number and structure of NMS.

Materials and Methods: This observational cross-sectional pilot study was conducted at the Department of Neurology, University Hospital of Split. This study lasted from November 2017. to April 2018. and it included 31 patients, hospitalized or treated in the infirmary at the Department of Neurology. By examining medical documentation we acquired necessary demographic and medical information about our subjects. Subjects were then examined and subjected to filling out Parkinson's disease-specific questionnaires: NMSQuest, Hoehn\&Yahr scale, UPDRS, and Schwab\&England scale. To analyze given variables we used the Mann-Whitney U test, Kruskal-Wallis test, Spearman's coefficient of correlation, and $\chi 2$ test.

Results: On average 12 dwifferent NMS were reported per patient. Most prevalent NMS were reported to be nocturia $(67.74 \%)$, urinary urgency $(61.29 \%)$, constipation $(61.29 \%)$, intense dreams $(58.06 \%)$, and forgetfulness $(58.06 \%)$. The least prevalent NMS reported were delusions $(6.45 \%)$, hallucinations $(16.12 \%)$, and daytime sleepiness (25.80\%). There were neither statistical differences in the total number of NMS nor in demographic variables between men and women. The increased burden of NMS correlated with the disease duration. Prevalence of depression, anxiety, and miscellaneous symptoms rose with the length of disease duration. We established a connection between the number of NMS and the stage of disease according to Hoehn and Yahr. Patients in higher stages of disease (moderate and severe) reported more severe NMS burden than patients in the mild stage of the disease, while patients in the moderate stage had the largest NMS score of all groups. Patients in the mild stage reported urinary, also digestive, and cognitive symptoms, in the moderate stage urinary symptoms, sexual dysfunction, and cardiovascular symptoms were most reported, while in the severe stage of the disease, patients reported cardiovascular symptoms, depression, and anxiety alongside urinary symptoms as most prevalent.

Conclusions: Patients are most affected by the autonomic spectrum of NMS, especially urinary symptoms. Duration of the disease and stage of the disease are proven to affect the total number of NMS, while age at onset, current age, and sex have been disproven to have any effect on the total NMS score. Patients in the moderate stage reported the most NMS.

KeYWORDS: Parkinson's Disease, Non - motor symptoms, questionnaire 


\section{SAŽETAK:}

UČESTALOST NEMOTORIČKIH SIMPTOMA U BOLESNIKA S PARKINOSNOVOM BOLESTI U SPLITSKO-DALMATINSKOJ ŽUPANIJI

Uvod: Cilj ove studije bio je istražiti učestalost NMS-a u bolesnika oboljelih od Parkinsonove bolesti u Splitsko-dalmatinskoj županiji te učinke ostalih varijabli na broj i strukturu NMS-a.

Materijali i metode: Ova opisno presječna pilot studija provedena je na Klinici za neurologiju, Kliničkog bolničkog centra Split. U studiji koja je trajala od studenog 2017. do travnja 2018. sudjelovao je 31 bolesnik, hospitaliziran ili liječen u ambulanti na Klinici za neurologiju. Uvidom u medicinsku dokumentaciju prikupili smo potrebne demografske i medicinske podatke o našim ispitanicima. Ispitanici su zatim pregledani i podvrgnuti popunjavanju upitnika specifičnih za Parkinsonovu bolest: NMSQuest, skala Hoehn \& Yahr, UPDRS i skala Schwab \& England. U statističkoj obradi podataka koristili smo Mann-Whitney U test, Kruskal-Wallisov test, Spearmanov koeficijent korelacije i $\chi 2$ test. Rezultati: U prosjeku 12 različitih NMS-a je prijavljeno po ispitaniku. Najzastupljeniji pojedinačno prijavljeni NMS bili su nokturija $(67,74 \%)$, urinarna inkontinencija $(61,29 \%)$, konstipacija $(61,29 \%)$, intenzivni snovi $(58,06 \%)$ i zaboravljivost $(58,06 \%)$. Najrjeđe prijavljeni NMS-i bili su deluzije $(6,45 \%)$, halucinacije $(16,12 \%)$ i dnevna pospanost $(25,80 \%)$. Između muškaraca i žena nismo ustanovili statistički značajne razlike u ukupnom broju NMS-a, niti u demografskim značajkama bolesti. Porast duljine trajanja bolesti korelirao je s porastom opterećenja NMS-a. Depresija, anksioznost i simptomi domene razno značajno rastu s porastom duljine trajanja bolesti. Ustanovili smo povezanost broja NMS-a sa stadijem bolesti po Hoehn i Yahru. Bolesnici u većim stadijima (srednji i teški) bolesti imali su više NMS-a, $s$ tim da su bolesnici srednjeg stadija bolesti u našem istraživanju imali najviše NMS-a. Kroz sve stadije bolesti simptomi mokrenja najviše opterećuju bolesnike. U blagom stadiju bolesti ispitanike uz mokrenje opterećuju simptomi probave i kognicije, u srednjem stadiju problemi spolnog odnosa i kardiovaskularni problemi, a u teškom stadiju bolesti uz kardiovaskularne probleme, depresija i anksioznost.

Zaključci: Bolesnike najviše opterećuje autonomni spektar NMS-a, posebno simptomi mokraćnog sustava. Na ukupni broj NMS-a utječe duljina trajanja bolesti i stadij bolesti, a ne utječe dob postavljanja dijagnoze, trenutna dob i spol. Bolesnici srednjeg stadija bolesti prijavili su najviše NMS-a.

KLJUČnE RIJEČI: Parkinsonova bolest, Nemotorički simptomi, upitnik

\section{INTRODUCTION}

In 1817. James Parkinson recognized the importance of motor symptoms of then called „shaking palsy“ and identified key non-motor symptoms, such as autonomic dysfunction, disorders of sleep, cognitive and neuropsychiatric symptoms ${ }^{1}$. Today, two hundred years later, the nonmotor symptoms (NMS) of PD are still often overlooked. A prospective study involving 101 patients found that neurologists do not discuss serious symptoms such as depression, anxiety, fatigue, and sleep disturbance with more than $50 \%$ of patients. These results may be due to the limited time spent with the patient, the misperception of the patient or caregiver that their symptoms are not related to the disease, or the lack of awareness of physicians who then direct the conversation toward motor symptoms. In addition to neurologists, an international study conducted in 2010 found that $62 \%$ of patients did not report symptoms such as apathy, pain, sexual dysfunction, sleep disorders, and stool incontinence because they were uncomfortable or unaware that these symptoms were associated with PD. It is for these reasons that questionnaires such as the Non-Motor Symptoms Questionnaire (NMSQuest) and the Non-Motor Symptoms Scale (NMSS) have recently been developed to help clinicians quantify the overall burden of nonmotor symptoms and their impact on the quality of life. NMSQuest is a questionnaire that contains thirty most common non-motor symptoms and the patient answers each of them with "yes" or "no". It is designed to help patients flag certain symptoms that they find troublesome but often overlook when visiting their neurologist, and to assist the busy clinician in steering the examination and history taking in the right direction ${ }^{2,3}$.

Parkinson's disease can be divided into the preclinical phase (supported by molecular and imaging markers), the premotor phase (with early non-motor symptoms), and the motor phase, which 
is the "tip of the iceberg". Also, some non-motor symptoms dominate in the early or premotor phase (hyposmia, constipation), others are present during the entire duration of the disease (fatigue, pain), and others occur especially in the advanced stage of the disease (dementia, apathy, autonomic dysfunction). As the average life expectancy and life expectancy of the population increase, non-motor symptoms become increasingly important. The impact of nonmotor symptoms on quality of life has been proven to be crucial in numerous studies and if left untreated causes a significant decline in quality of life, hospitalization, and institutionalization which increases the cost of therapy fourfold. Also, nonmotor symptoms are useful biological markers in the diagnosis of PB. A study conducted in Germany comparing untreated patients with PD and a control group showed that diagnostic agents such as NMSQuest and SCOPA-autonomic (scale of autonomic symptoms) combined with laboratory tests such as the odor identification test achieve sensitivity and specificity ( > 0.9 ) adequate for a biological marker of PD development ${ }^{2,3}$.

\section{MATERIALS AND METHODS}

This was an observational cross sectional pilot study. It was conducted at the Department of Neurology, University Hospital Center Split. This study was in accordance with Ethics committee of University Clinical Hospital Split and all participants provided written informed consent according to the Declaration of Helsinki. We recruited 31 PD patients who were seen in Department of Neurology, University Clinical Hospital Split between December 2017. and April 2018. All participants met UK PD Society Brain Bank Clinical Diagnostic Criteria for PD. Exclusion criteria included patients with atypical and secondary PD, such as MSA.

Questioning of patients would start with the taking of routine demographic data (age, gender, etc.) and collecting information about their medical history. Afterwards patients would be examined by the movement disorder specialist and administered questionnaires which they had to fulfill. Questionnaires we used in our study were UPDRS, NMSQuest (Non - Motor Symptoms Questionnaire), Hoehn\&Yahr scale, and Schwab\&England scale. For this purpose NMSQuest was translated to Croatian with permission from holders of author rights International Parkinson and Movement Disorder Society (MDS). NMSQuest is envisioned to be a self completed screening tool in which patients themselves or with the help from caregiver answer thirty questions representing NMS with „Yes“ or „No“ in case they have felt one of those symptoms in the last thirty days. Thirty individual NMS are then divided in nine different domains: seven NMS fall in „Digestion“ domain, two in „Urinary“, three „Cognition“, two "Hallucination/Delusion“, two „Depression/Anxiety“, two „Sexual function“, two „Cardiovascular“, five „Sleep disorder“, and five „Miscellaneous“ (unexplained pain, weight change, falling, sweating, diplopia). Prevalence of each NMS was calculated by adding the number of positive answers and transforming it to a percentage. To examine the number of NMS in different groups and domains we quantified the number of positive answers for each patient, group, domain (men - women, patients younger/older than 70 years, etc.) transformed them to median or percentage and compared them to each other.

UPDRS (Unified Parkinson's disease rating scale) is a standard scale used to follow the progression of PD during clinical examinations. It contains in it non motor symptoms, motor symptoms, and treatment side effects. For quantifying results of UPDRS we used internet UPDRS calculator farmacologiaclinica. info. Schwab\&England scale is a standardized daily activities scale for PD patients. It is used to asses the percentage of daily activities in which PD patients participate, and the need for additional support. It is measured in percentages with $100 \%$ meaning total independence of patients, and $0 \%$ meaning patients are bed ridden, and his/her vegetative functions are failing. After complete neurologic assessment patients were divided in different stages of disease according to Hoehn\&Yahr scale. With 1-2,5 stages being mild, stage 3 being moderate, and stages 4 and 5 being severe. All questionnaires except NMSQuest were previously translated to Croatian. Data analytics were done using a statistical software IBM SPSS Statistics version 20, 2011. ( New York, USA). We interpreted results with $\mathrm{P}<0,05$ as significant, and in comparing different groups, and domains and associations between them used Mann - Whitney U test, Kruskal - Wallis test, Spearman coefficient of correlation, and $\chi 2$ test. Spearman coefficient of correlation $<0,3$ presented insignificant correlation; from 0,3 to 0,59 presented slight correlation, $>=0,6$ presented significant correlation, and $>=0,7$ presented very significant correlation of researched data.

\section{RESULTS}

In our pilot study there were 31 patients with PD treated in University Hospital Center Split. Examination and fulfillment of questionnaires took place from November 2017. till April 2018. Of all patients 14 (45\%) were women, and 17 (55\%) were men. Median of age at which diagnosis was made was 59 years (Q1Q3:52-66;min.-max.:41-83). Median of the duration of disease was 8 years (Q1-Q3:5-15;min.-max.:1-24). Median of age during examination was 70 years (Q1-Q3:64-75;min.-max.:46-85). As seen from Table 1. there was no significant statistical difference between men and women concerning these variables. 
Table 1. Age when disease was diagnosed, duration of disease, age at examination in relation to gender

\begin{tabular}{|c|c|c|c|}
\hline \multicolumn{4}{|c|}{ Median $(Q 1-Q 3 ; \min -\max )$} \\
\hline & Men & Women & $P^{*}$ \\
\hline & $(n=17)$ & $(n=14)$ & \\
\hline Age at diagnosis & $56(53-65 ; 41-83)$ & $62,5(52-66 ; 46-72)$ & 0,382 \\
\hline Duration of disease & $8(5-13 ; 2-17)$ & $8,5(6,5-15 ; 1-24)$ & 0,369 \\
\hline Age at examination & $65(62-72 ; 46-85)$ & $71(66-77 ; 58-83)$ & 0,136 \\
\hline
\end{tabular}

*Mann - Whitney U test

From the total number of patients 17 (55\%) were in mild stage of the disease (according to Hoeh\&Yahr scale), 5 (16\%) were in moderate stage, and $9(29 \%)$ were in severe stage. Median of total NMS was 12 (Q1-Q3:8-16;min.-max.:1-26). In average patients reported 12 different NMS (12 \pm 6$)$. All patients had at least one NMS, while one patient reported whooping 26 NMS from possible 30. Percentage of individual NMS according to data collected from NMSQ are shown in Table 2.

We then divided patients in to groups according to the median of age at diagnosis (59), median of duration of disease ${ }^{8}$, median of age at examination (70), and according to the stage of the disease. Results we got from data analysis of these groups is shown in Table 3. There was no statistically significant difference in results of NMSQuest between men and women $(Z=0,875 ; P=0,381)$, between those patients that were diagnosed with PD before or after their $59^{\text {th }}$ year $(\mathrm{Z}=0,139 ; \mathrm{P}=0,890)$, and between those patient that were younger or older than 70 years $(\mathrm{Z}=0,951 ; \mathrm{P}=0,342)$. We proved statistically significant difference in NMSQuest results between patients with the duration of disease less than 8 years and those in which disease lasted longer than 8 years $(\mathrm{Z}=2,4 ; \mathrm{P}=0,017)$. Patients with longer lasting disease had scored 5 more NMS than patients who had shorter lasting disease. We found statistically significant association of NMSQuest results with the stage of disease $(\mathrm{H} \& \mathrm{Y})(\chi 2=11,8 ; \mathrm{P}=0,003)$. Both patients in moderate $(\mathrm{P}=0,021)$ and severe stage $(\mathrm{P}=0,015)$ had significant difference in NMSQuest scores compared to patients in mild stage. Median of NMS for moderate stage patients was larger for 9 points in comparison to patients with mild stage. Median of NMS for severe stage patients was larger for 7 points compared to patients in mild stage. NMSQuest has nine domains and using Spearman coefficient of correlation we found statistical significant association between certain domains. Digestive symptoms domain has mild association with urinary symptoms domain $(\rho=0,356 ; P=0,049)$ with cognitive symptoms domain $(\rho=0,457 ; P=0,010)$, and with hallucination domain $(\rho=0,412$; $\mathrm{P}=0,021)$, and significant association with sleep disorders domain $(\rho=0,638 ; P<0,001)$, and miscellaneous domain $(\rho=0,621$; $\mathrm{P}<0,001)$. Urinary domain has slight association with sleep disorders domain $(\rho=0,412 ; P=0,021)$. Cognitive symptoms domain has slight association with sexual function $(\rho=0,383 ; \mathrm{P}=0,034)$, hallucinations $(\rho=0,466 ; P=0,008)$ and miscellaneous domain $(\rho=0,363 ; P=0,045)$. Depression and anxiety has almost significant association with miscellaneous $(\rho=0,597 ; P<0,001)$. Sleep disorders has slight association with cardiovascular $(\rho=0,517$; $P=0,003)$ and with miscellaneous domain $(\rho=0,516 ; P=0,003)$. Linear association of NMS with duration of disease in our patients was statistically significant for depression/anxiety $(\rho=0,660)$ and miscellaneous domain $(\rho=0,425)$. We found statistically significant association of NMS total score with duration of disease (Table 4.). 
Table 2. Percentage of individual NMS

\begin{tabular}{|c|c|c|}
\hline NMS & $\mathrm{N}=31$ & $\%$ \\
\hline Dribbling & 15 & 48,38 \\
\hline Loss of taste/smelling & 14 & 45,16 \\
\hline Swallowing difficulties & 13 & 41,93 \\
\hline Vomiting & 9 & 29,03 \\
\hline Constipation & 19 & 61,29 \\
\hline Bowel incontinence & 9 & 29,03 \\
\hline Incomplete bowel emptying & 15 & 48,38 \\
\hline Urgency & 19 & 61,29 \\
\hline Nocturia & 21 & 67,74 \\
\hline Unexplained pain & 12 & 38,70 \\
\hline Weight change & 9 & 29,03 \\
\hline Forgetfulness, memory & 18 & 58,06 \\
\hline Loss of interest & 13 & 41,93 \\
\hline Hallucinations & 5 & 16,12 \\
\hline Problems concentrating & 11 & 35,48 \\
\hline Depression & 13 & 41,93 \\
\hline Anxiety & 12 & 38,70 \\
\hline Sex drive & 15 & 48,38 \\
\hline Sex difficulty & 10 & 32,25 \\
\hline Vertigo & 17 & 54,83 \\
\hline Falling & 9 & 29,03 \\
\hline Daily sleepiness & 8 & 25,80 \\
\hline Insomnia & 10 & 32,25 \\
\hline Intense dreams & 18 & 58,06 \\
\hline Acting out during dreams & 15 & 48,38 \\
\hline Restless legs & 15 & 48,38 \\
\hline Leg swelling & 14 & 45,16 \\
\hline Sweating & 9 & 29,03 \\
\hline Diplopia & 12 & 38,70 \\
\hline Delusions & 2 & 6,45 \\
\hline
\end{tabular}


Table 3. Comparison of NMS between different patient groups

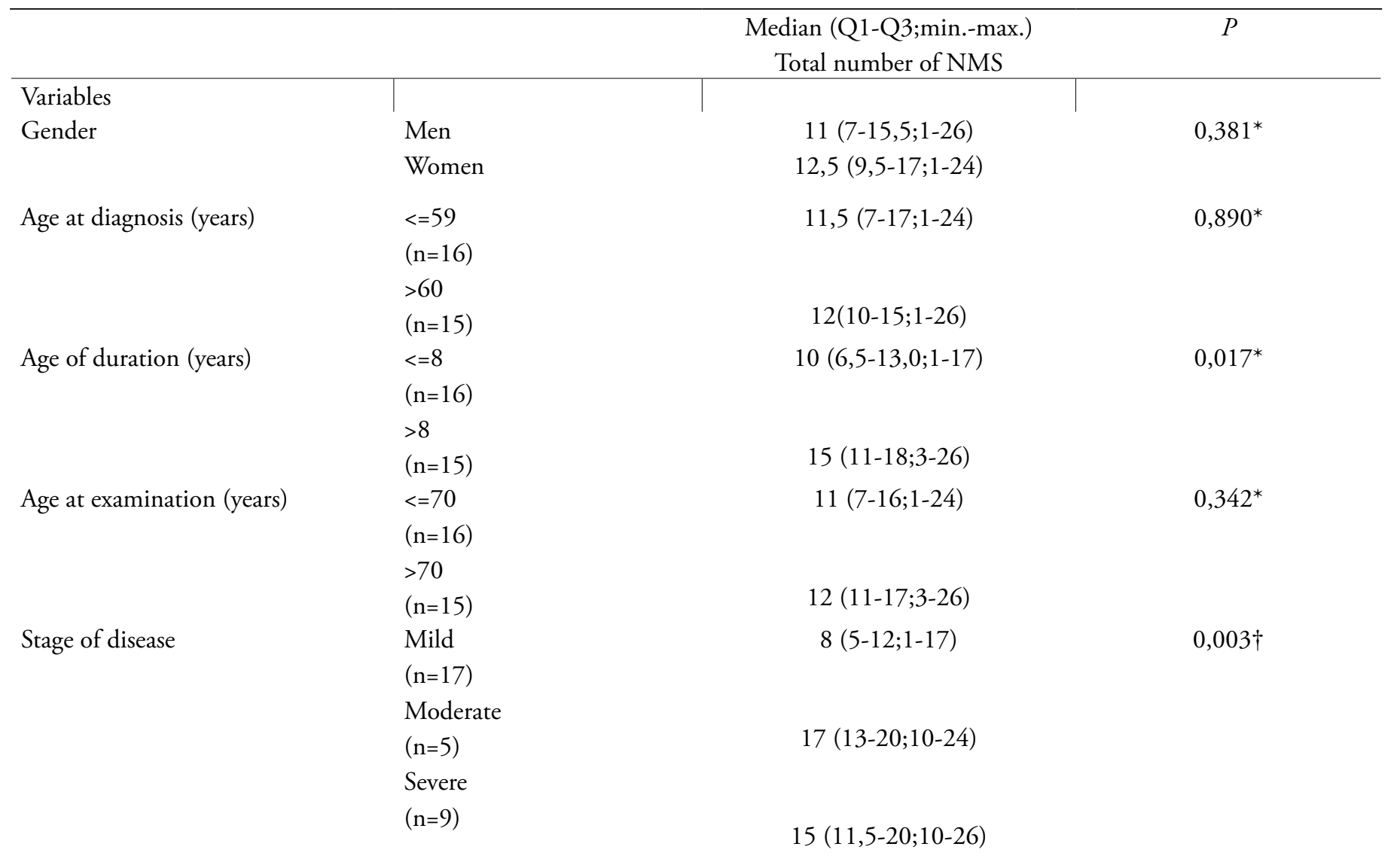

*Mann-Whitney U Test $†$ Kruskall-Wallis Test 
NMS Urinary

NMS Cognition

NMS Depression/Anxiety

NMS Sexual function

NMS Cardiovascular

NMS Hallucinations

NMS Sleep disorders

When comparing domains of NMSQuest with stages of disease according to $\mathrm{H} \& \mathrm{Y}$ we found that the patients in mild stage of disease are mostly bothered by the symptoms of urinary (47\%), cognitive (37\%), and digestive dysfunction (34\%). Patients in moderate stage complained the most on urinary (90\%), sexual function $(70 \%)$, and cardiovascular symptoms (70\%). Patients in severe stage were complaining on urinary $(83 \%)$, cardiovascular $(83 \%)$, and depression and anxiety $(67 \%)$ (Table 5.$)$. 
Table 5. NMS points in domains compared amongst different stages of $P D$

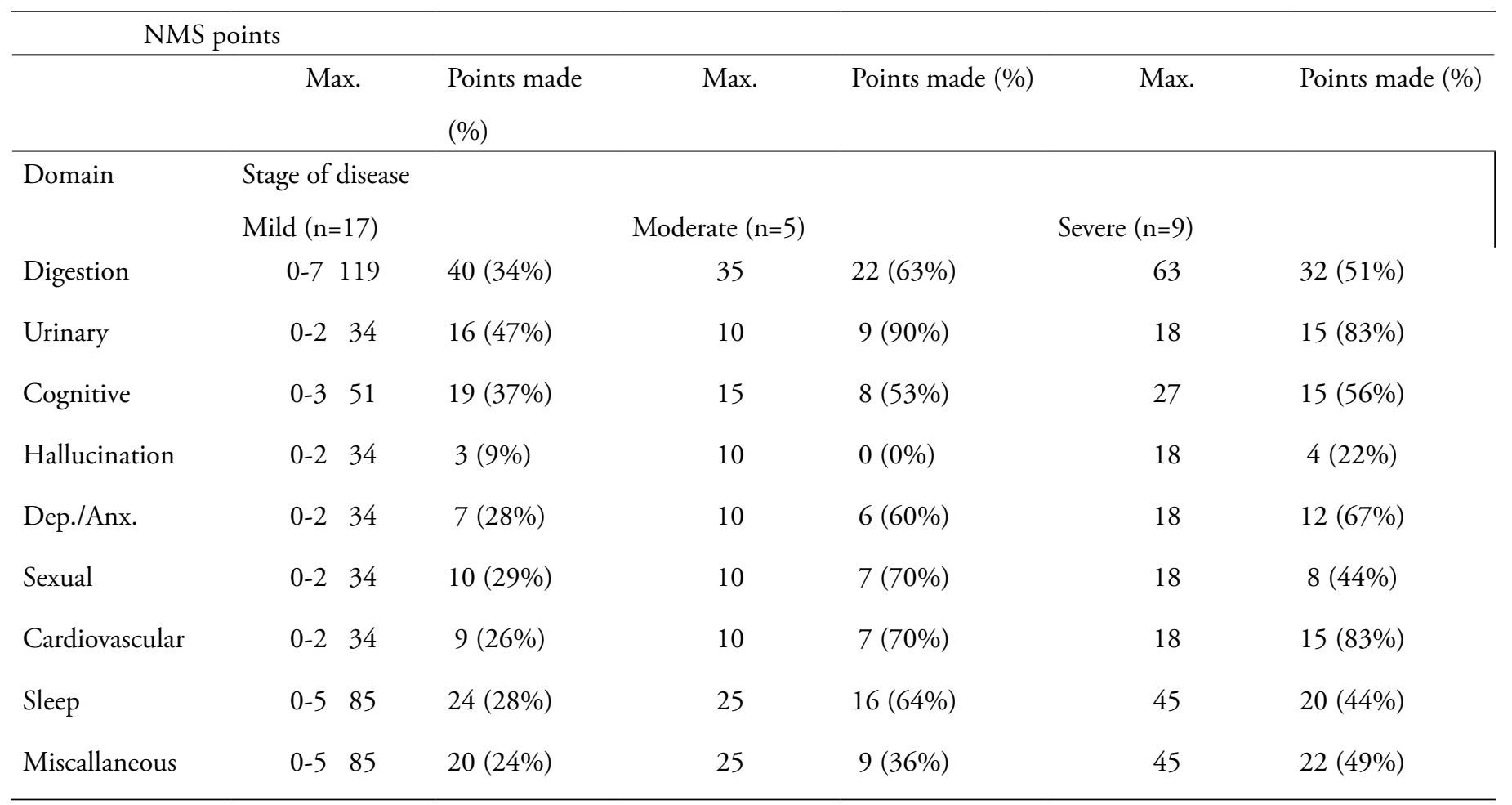

Legend: Max. is the maximum possible number of positive answers for each group ( for example in mild stage disease with 17 patients if all scored 7 in digestive domain, total score would be 119; for urinary domain which has 2 questions total score would be 34). Points made is the sum of points scored by the patients of each stage. Abbreviations: Dep.- depression, Anx.- anxiety.

We found statistically significant differences of domain results amongst stages of PD with digestive domain $(\chi 2=6,9 ; \mathrm{P}=0,032)$ (difference being made by patients in moderate stage compared to mild $(\mathrm{P}=0,043)$, urinary $(\chi 2=6,9 ; \mathrm{P}=0,032)$ (moderate stage compared to mild $(\mathrm{P}=0,05)$, and sever compared to mild $(\mathrm{P}=0,05)$, depression and anxiety $(\chi 2=7,2 ; \mathrm{P}=0,027)$ (severe compared to mild stage $(\mathrm{P}=0,037)$, cardiovascular domain $(\chi 2=12,8$; $\mathrm{P}=0,002)$ (severe compared to mild $(\mathrm{P}=0,002)$ ), and sleep dysfunction domain $(\chi 2=6,9 ; \mathrm{P}=0,031)$ (moderate compared to mild $(\mathrm{P}=0,037)$ ). (Table 5.).
We didn't find statistically significant difference of domain results between stages for cognitive domain $(\chi 2=2,3 ; \mathrm{P}=0,314)$, hallucinations $(\chi 2=1,3 ; \mathrm{P}=0,507)$, sexual function $(\chi 2=3,4 ; \mathrm{P}=0,179)$ and miscellaneous $(\chi 2=4,9 ; \mathrm{P}=0,084)$ (Table 5.). All used questionnaires had statistically significant high and very high correlation between them $(\mathrm{P}<0,001)$ (Table 6.) Total results of NMSQuest had significant correlation with total UPDRS score, and percentage of daily activities disability (Table 6.). 


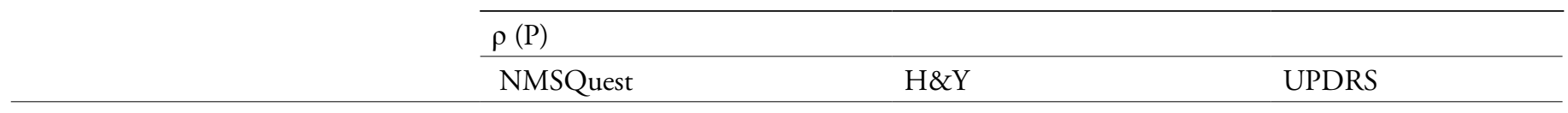

Questionnaire results

Hoehn\&Yahr

UPDRS

0,810

$(<0,001)$

Schwab\&England
$-0,642(<0,001)$
$-0,844$

$(<0,001)$
$0,769(<0,001)$

All questionnaires were significantly associated with the duration of PD: Hoehn\&Yahr $\rho=0,391$ ( $P=0,029)$, UPDRS $\rho=0,456$ ( $P=0,010)$, Schwab\&England $\rho=-0,388$ $(\mathrm{P}=0,031)$.

\section{DisCUSSION}

NMS are a great burden of almost every PD patient. Nevertheless, they are still poorly recognized and treated. With that thought in mind, we ventured in making of this pilot study in which the main goals were to show the prevalence of different NMS, and the effects of different variables such as duration, and stage of disease on NMS. One of the reasons NMS are not getting the recognition they deserve is because patients often find it uncomfortable to talk about them, or they think of the symptoms as part of aging. In our study, we witnessed that some of our patients had difficulty scoring symptoms such as sexual function, hallucinations, etc. Our observation is confirmed by a study done by K.Ray Chaudhuri et al. ${ }^{4}$ who established that in average 4 NMS per patient are not told off to the physician. In our study, all patients reported at least one NMS which is per other studies in which at least one NMS was prevalent in $97,6 \%$ ${ }^{5}, 98,4 \%(6)$, and $99,3 \%{ }^{7}$ patients. On average 12 different NMS were reported per patient in our study which is close to an average of 10 NMS reported in previous studies ${ }^{5,6}$. An average number of 12 NMS signifies a severe stage of disease according to criteria for grading of NMSQuest results established in research done by K. Ray Chaudhuri et al ${ }^{8}$. Individually most prevalent NMS were autonomic symptoms such as nocturia $(67,74 \%)$, urgency $(61,29 \%)$, constipation $(61,29 \%)$, intense dreams $(58,06 \%)$ and forgetfulness $(58,06 \%)$. These results are mostly following a much larger study done by Pablo Martinez Martin et al. ${ }^{6}$, in which most prevalent NMS were nocturia
(61,90\%), urgency $(55,81 \%)$, constipation $(52,48 \%)$, depression $(50,10 \%)$, and forgetfulness (44,85\%). A study done by Praween Lolekh et al. ${ }^{9}$ also shows a great prevalence of urinary symptoms (nocturia 79,1\% and urgency 73\%). The least prevalent NMS in our study were delusions $(6,45 \%)$, hallucinations $(16,12 \%)$, and day time sleepiness (25,80\%). Prevalence of delusions and hallucinations is rare, and usually is present in patients in which the duration of the disease is longer, they are in advanced age, have a poor cognitive reserve, and use a larger dosage of dopaminergic drugs. Concerning hallucinations and delusions our results are following other studies ${ }^{6,9}$, even thou some of the symptoms such as incontinence are even less prevalent.

We found that there was no statistically significant difference between the total number of NMS between men and women, and these results are mostly in accordance with previous studies $5,6,10,11$ which also report non-significant differences. Then again study done by Martinez Martin et al. ${ }^{11}$ went into a deeper analysis of differences between male and female PD patients. They found that women are more likely to report tiredness, anxiety, depression, constipation, restless legs, and pain, while men are more likely to report day time sleepiness, dribbling, change in sex drive, and problems with sexual function.

Our study shows that the age at which diagnosis is made and age during an examination of patients did not correlate with the total number of NMS. Contrary to that, the duration of disease showed a significant effect on the total number of NMS telling us that with the longer duration of the disease the burden of 
NMS grows ever larger. Those findings are following previous research $^{5,6,10,12}$. In between specific domains we found that the number of symptoms of depression, anxiety, and miscellaneous significantly rises with the longer duration of disease. We explain that with a longer duration of disease a combination of disease pathophysiology and patient's psychological mechanisms crumbling, due to losing hope in treatment possibilities, gives rise to more depression and anxiety being prevalent with such patients. Symptoms of miscellaneous domain rise with longer duration of disease as side effects of therapy mount up, and symptoms such as unexplained pain, and weight change can be caused by more often on-off periods causing rigor and gastroparesis in longerlasting disease. Also, these findings are following a larger multicenter study done by M.A Hely et al. ${ }^{13}$ in which they discovered that non-L-dopa symptoms such as depression, anxiety, falling, etc. dominate with longer duration of disease. A much larger study done by Paolo Barone et al. ${ }^{14}$ showed conflicting results putting depression and other psychiatric symptoms in a group of those NMS which were unaffected with longer duration of disease. The difference could be explained by our smaller sample of patients, and differences in cultures of examined patients. We found that patients which had digestive symptoms more often complained on urinary $(\rho=0,356 ; P=0,049)$, cognitive $(\rho=0,457$; $\mathrm{P}=0,010)$, sleeping $(\rho=0,638 ; \mathrm{P}<0,001)$, hallucination $(\rho=0,412$; $\mathrm{P}=0,021)$, and miscellaneous symptoms $(\rho=0,621 ; \mathrm{P}<0,001)$. Those patients that reported cognitive symptoms more often reported sexual dysfunction $(\rho=0,383 ; P=0,034)$, hallucinations $(\rho=0,466 ; P=0,008)$ and miscellaneous symptoms $(\rho=0,363$; $\mathrm{P}=0,045)$. These findings can be explained by the neuropathological progress of PD. Because digestive symptoms such as constipation, dribbling, and incomplete bowel emptying represent symptoms which are present in Braak stages 1 thru $6^{15}$, with pathology happening from the dorsal motor nerve of Vagus, and to gastroesophageal plexus to sympathetic and parasympathetic ganglia it poses no surprise that they are present with all other symptoms that encompass different Braak stages of neuropathology, meaning that digestive symptoms are a common denominator in all stages of PD ${ }^{16}$. Cognitive symptoms of PD represent the last stage of disease progression together with hallucinations, sexual dysfunction, unexplained pain, and falling. These symptoms represent Braak stages 4 to 6 of $\alpha$ Syn pathology ${ }^{15,16}$. There have been numerous studies that proved both epidemiological and neuroimaging association between cognitive symptoms and hallucinations ${ }^{17,18,19,20}$ A study done by Pablo Martinez Martin et al ${ }^{6}$ found a correlation only among depression/anxiety domain with a urinary and cognitive domain.

NMS are present in all stages of the disease. Our findings of correlation of the total number of NMS with disease stage according to Hoehn\&Yahr are following numerous other studies ${ }^{5-7,21-23}$. We found that patients of the moderate and severe stage had significantly higher NMS burden than patients in the mild stage of the disease. What is specific for our pilot study is that patients in a moderate stage of the disease reported the highest number of NMS. We try to explain it with the fact that patients in the moderate stage still have their motor symptoms adequately compensated and thus their focus is on NMS which are harder to control with pharmacotherapy. Compared to them the focus of patients in the severe stage of the disease is on more severe motor symptoms which come with disease progression, while simultaneously they ignore some of the NMS as not connected to PD.

Other research shows a continuous rise in NMS number together with the stage of disease in which patients in the severe stage have the highest number of NMS ${ }^{5-8,9}$. Once again our small sample may be a confounding factor, also the prevailing culture among examined patients gives primary focus on motor symptoms which prevents them from doing daily activities. According to Hoehn\&Yahr stage patients in the mild stage were most troubled by urinary (47\%), cognitive (37\%), and digestive symptoms (34\%). Patients in the moderate stage were most troubled by urinary $(90 \%)$, digestive $(70 \%)$, and cardiovascular symptoms $(70 \%)$, while patients in the severe stage were most troubled by urinary $(83 \%)$, cardiovascular $(83 \%)$ and depression and anxiety symptoms (67\%). With the average age of patients being 70 years it comes with no surprise that patients in the mild stage of disease complain about cognitive symptoms. These results are following Braak et al. ${ }^{15}$ hypothesis of disease pathophysiology. We found that all questionnaires used had significant correlations among themselves and with the duration of disease. It means that with a longer duration of disease of examined patients they had higher UPDRS scores, they were in a higher stage of the disease, and their daily activities diminished. Those results are in accordance with previous studies ${ }^{9,12}$ and show that NMSQuest is a reliable source of information not only concerning NMS but also the progress and staging of disease. NMSQuest presented itself as a useful way of presenting symptoms that concern patients which would otherwise be missed. In a modern and all-encompassing approach to $\mathrm{PD}$, it is important to direct more attention to NMS and to find an adequate way of ameliorating these symptoms. Limitations of our pilot study are its small number of participants and focus on only those patients treated at University Hospital Center Split. Nevertheless, this pilot study confirms the potential in examining NMS symptoms of PD on a much broader scale in Croatia. 


\section{REFERENCES:}

1. Parkinson J. An essay on the shaking palsy. J Neuropsychiatry Clin Neurosci. 2002: 14: 223-36;

Discussion, 222

2. Todorova A, Jenner P, Chaudhuri KR. Non-motor Parkinson's: integral to motor Parkinson's, yet often neglected. Pract Neurol. 2014;14(5):310-22.

3. Chaudhuri KR, Healy DG, Schapira AHV. Non-motor symptoms of Parkinson's disease: diagnosis and management. Lancet Neurol. 2006;5(3):235-45.

4. Chaudhuri KR, Prieto-Jurcynska C, Naidu Y, Mitra T, Frades-Payo B, Tluk S et al. The Nondeclaration of Nonmotor Symptoms of Parkinson's Disease to Health Care Professionals: An International Study Using the Nonmotor Symptoms Questionnaire. Mov Disord. 2010;25(6):704-9.

5. Chaudhuri KR,Martinez-Martin P, Schapira AHV, Stocchi F, Sethi K, Odin P et al. International Multicenter Pilot Study of the First Comprehensive Self-Completed Nonmotor Symptoms Questionnaire for Parkinson's Disease: The NMSQuest Study. Mov Disord. 2006;21(7):916-23.

6. Martinez-Martin P, Schapira AHV, Stocchi F, Sethi K, Odin P, MacPhee G et al. Prevalence of Nonmotor Symptoms in Parkinson's Disease in an International Setting; Study Using Nonmotor Symptoms Questionnaire in 545 patients. Mov Disord. 2007;22(11):1623-29.

7. Santos-García D, de la Fuente-Fernández R. Impact of nonmotor symptoms on health-related and percieved quality of life in Parkinson's disease. J Neurol Sci. 2013;332(1-2):136-40.

8. Chaudhuri KR, Sauerbier A, Rojo JM, Sethi K, Schapira AHV, Brown RG et al. The burden of non-motor symptoms in Parkinson's disease using a self-completed non-motor questionnaire: A simple grading system. Parkinsonism Relat Disord. 2015;21(3):287-91.

9. Lolekha P, Kulkantrakorn K. Non-motor symptoms in Thai Parkinson's disease patients: Prevalence, manifestation and health related quality of life. Neurol Asia. 2014;19(2):163 70.

10. Breen KC, Drutyte G. Non-motor symptoms of Parkinson's disease: the patient's perspective. J Neural Transm. 2013;120(4):531-5.

11. Martinez-Martin P, Pecurariu CF, Odin P, Van Hilten JJ, Antonini A, Rojo-Abuin JM et al. Gender-related differences in the burden of non-motor symptoms in Parkinson's disease. J Neurol. 2012;259(8):1639-47.
12. Li H, Zhang M, Chen L, Zhang J, Pei Z, Hu A et al. Nonmotor Symptoms Are Independently Associated With Impaired Health-Related Quality of Life in Chinese Patients With Parkinson's disease. Mov Disord. 2010;25(16):2740-6.

13. Hely MA, Morris JGL, Reid WGJ, Trafficante R. Sydney Multicenter Study of Parkinson's Disease:

Non-L-Dopa-Responsive Problems Dominate at 15 Years. Movement Disorders. 2005:20(2):190-99.

14. Barone P, Antonini A, Colosimo C, Marconi R, Morgante L, Avarello TP et al. The Priamo Study: A Multicenter Assessment of Nonmotor Symptoms and Their Impact on Quality of Life in Parkinson's disease. Mov Disord. 2009;24(11):1641-9.

15. Braak H, Tredici KD, Rüb U, de Vos RAI, Steur ENHJ, Braak E. Staging of brain pathology related to sporadic Parkinson's disease. Neurobiol Aging. 2003;24(2):197-211.

16. Jellinger KA.Neuropathobiology of non-motor symptoms in Parkinson disease. Journal of Neural Transmission. 2015:122:1429-40.

17. Fénelon G, Alves G. Epidemiology of psychosis in Parkinson's disease. J. Neurol. Sci. 2010:289:12-7.

18. Ramirez-Ruiz B, Junque C, Marti MJ, Valldeoriola F, Tolosa E. Cognitive changes in Parkinson's disease patients with visual hallucinations. Dement. Geriatr. Cogn. Disord. 2007:23:281-288.

19. Katzen H, Myerson C, Papapetropoulos S, Nahab F, Gallo B, Levin B. Multimodal hallucinations and cognitive function in Parkinson's disease. Dement. Geriatr. Cogn. Disord. 2010:30: 51-56.

20. Ibarretxe-Bilbao N, Ramírez-Ruiz B, Tolosa E, Martí MJ, Valldeoriola F, Bargalló N, Junqué C. Hippocampal head atrophy predominance in Parkinson's disease with hallucinations and with dementia. J. Neurol. 2008:255:1324-31.

21. Leonardi M, Raggi A, Pagani M, Carella F, Soliveri P, Albanese A et al. Relationship between disability, quality of life and prevalence of nonmotor symptoms in Parkinson's disease. Parkinsonism Relat Disord. 2012;18:35-9.

22. Dotchin CL, Jusabani A, Walker RW. Non-motor symptoms in a prevalent population with Parkinson's disease in Tanzania. Parkinsonism Relat Disord. 2009;15(6):457-60.

23. Gan J, Zhou M, Chen W, Liu Z. Non-motor symptoms in Chinese Parkinson's disease patients. J Clin Neurosci. 2014; 21(5):751-4. 
